\title{
The Use of Digital Storytelling in Teaching Plot in Narrative Writing for Year 4 Pupils in a Primary School
}

\author{
Patrisha A/P David, Azlina Abdul Aziz
}

\begin{abstract}
Narrative writing in ESL classrooms is usually seen as a complex process. However, the need to help the pupils to produce a narrative essay is becoming crucial as it is a part of the UPSR examination (Primary School Evaluation Test), which carries a very high weight-age of marks for that particular session. Therefore, Digital Storytelling used as a tool to help pupils to produce better narratives. This study reports quasiexperimental research on the use of Digital Storytelling in teaching plot development in narrative writing for year-4 pupils in an urban primary school. 30 pupils were chosen using purposive sampling in a school in Kuala Lumpur, Malaysia. A pre-test of narrative writing was administered to evaluate the participants' writing skills. The quasi-experimental research design was used to conduct this study. The participants were separated into two different groups: one experimental group and one control group. The participants of the experimental group used Digital Storytelling, focusing on plot development to produce a narrative text while the control group received a conventional method of teaching narrative writing. Finally, all the participants answered a post-test of producing narrative writing. Besides pre-test and post-test, the data was qualitatively gathered using Feedback Form, Semi-structured Interview of 4 participants, and Document Analysis of the narrative text produced. This effective, innovative strategy can be used to develop pupils' narrative writing skills on many levels besides year-4 pupils.
\end{abstract}

Keywords:Digital Storytelling, narrative writing, primary ESL learners and technology in education

\section{INTRODUCTION}

Nurturing ESL learners with 21st-century skills has gradually become an important agenda of the Ministry of Education (MOE) in Malaysia. Ministry of Education has taken many initiatives to encourage the teachers to equip the students with 21st-century skills by introducing National Blueprint (2013-2025) as a proactive approach to transform the current education system by directing the focus from teachers to the learners. The content of the Blueprints shows the Ministry's effort in preparing students to meet the global

Revised Manuscript Received on April 15, 2020.

* Correspondence Author

Patrisha David*, Sekolah Kebangsaan Seri Cheras, University Kebangsaan Malaysia, Bangi, Malaysia. Email: patrishadavid@hotmail.com

Azlina abdul Aziz, Faculty of Education, University Kebangsaan Malaysia, Bangi, Malaysia. Email: azlina1@ukm.edu.my

(C) The Authors. Published by Blue Eyes Intelligence Engineering and Sciences Publication (BEIESP). This is an open access article under the CC BY-NC-ND license (http://creativecommons.org/licenses/by-nc-nd/4.0/) competency equipped with 21st Century skills. 21st-century learners must have both self-direction and collaborative skills with groups and machines [34]. Thus, the teachers are expected to plan and conduct lessons that enable the students to drive own learning by generating new cognitive content, evaluating and analysing the presented materials, and application skill in various other situations based on the knowledge acquired.

Acquiring reading and writing skill alone does not make one literate in this 21 st century. In this modern world, “ one must be able to understand, exercise, study, synthesise, evaluate and create the information" [50]. The changes made in relation to the ideology of literacy force the educator to change the instruction method that witnesses the information, communication, and technology developing and evolving the whole education system. "The technology has an important role in improving education, and as a result, educators are obligated to integrate their area of mastery with technology" [2]. The advancement of Information and Communication Technology (ICT) has catered to the learners to take charge of their own learning, no matter where they are. The paradigm shift from acquiring core subject knowledge to developing skills is the main idea of 21st-century learning, which confronts the educators to change the whole instruction method.

Currently, the transition from a teacher-centred classroom to a student-centred classroom challenges many educators to equip the learners with autonomous and independent learning skills. Writing skills always been as one of the most complex skills as it needs the learners to produce the language in a systematic way. Writing is a cognitive process where, "the writer conveys their cognitive content, view, belief, experiences, events, and histories in written words in forms such as presenting it in letters, notes, shopping lists and many more" [33]. "Writing is always presumed as one of the most complex tasks involved by children or even adults, that is the reason it needs additional time and also strategies to acquire it" [26]. Reference [8] argues that, "writing is a constant process of thinking and organizing, rethinking and reorganising". Narrative writing is among the most challenging skill to be taught in an ESL classroom. On the other hand, [43] revealed that, "the learners transform to be better adjusted to acquiring target language if teachers pay more attention to the process of writing instead of stressing on the products of the writing". 
The Malaysian Ministry of Education has taken prominent steps to strengthen the English language by making the English language as a compulsory subject for all schools, and it is one of the important subjects in UPSR (Primary School Achievement Test), which is examined in two separate papers at the end of six years of primary schooling. The skill tested is mainly writing integrated with some elements of reading during the test. However, [3] it was found that Malaysian pupils' English language acquisition is still below satisfactory, as $70 \%$ of the pupils are still poor in the English language; despite that majority of pupils learnt it formally for at least eleven years - six years in primary school and in secondary school for five years. Narrative writing requires active intellectual activity and causes one to display the acquired skill into words of communication. Reference [37] states, that narrative writing is mostly individualised or personalised to share about the events which are related to an individual. Narrative writing enables one to be creative and narrate a series of events in an interesting manner to keep the reader engaged in the written text. A high level of language command is needed to create a good narrative text. The writer needs to be aware of tenses involved, action verbs, and other linguistic aspects. Reference [18] proposed that there are six linguistic characteristics of narrative text which are:

1. It is always very particularised, Humans or animals or even animals who portray human nature.

2. Primarily action verbs that demonstrate feelings or actions.

3. Usually past tense

4. Numerous linking verbs to do with the time

5. Dialogue frequently used according to the tenses used.

6. Usage of descriptive and figurative language to improve the story development.

Pupils need to be taught how to organise their thoughts so that they will be able to communicate it to other people who are reading it. Narrative writing allows active learning, whereby the brain uses the learned information to create a new idea. Reference [48] revealed that while producing narrative writing, pupils encounter various problems, using correct grammar in their writing and ways to get better ideas for better content. Teachers are required to intervene and guide them as they involve in this complex problem-solving process, as the process of writing matters than the outcome in narrative writing.

A particular individual's approach to teaching narrative writing will not fit the needs of every ESL learners. The English language practitioners are solely responsible for choosing a suitable approach and strategies in developing students' narrative writing skills as it is an essential lifelong skill that needs to be imparted to the pupils. Information and Communication Technology (ICT) is integrated into writing instruction for its outstanding and spectacular impact on pupils' writing [17]. Reference [54] found some advantages of integrating ICT in writing instruction were that it could draw pupils' attention, facilitate pupils' learning process, it helps to enhance pupils' vocabulary and promote meaningful learning. The use of technology will assist the students in being more imaginative and engaging in narrative writing as the pupils are over immersed in the technological world.

Using technology will be motivating the pupils to participate in the learning process actively and will also foster the construction of their knowledge through critical and reflective thinking. According to [51], "in this century, training pupils to master fluency and competence in various technologies is a fundamental part of teaching writing." The integration of technology can shift the learners' perception to acquire writing skills from negative to positive.

Storytelling is one of the exciting ways to assist the pupils in expressing themselves creatively. Digital storytelling is one of the 21st century emerging tools that enable students to approach their content critically and present the matter technically [42]. It encourages pupils to acquire 21st Century skills as well as to help them engage in writing tasks, which will help them to create a good piece of writing later on in their examination. Reference [28] states that, "Digital Storytelling considers most of the expected skills from 21st-century students". Reference [10] says that, "when visuals combined with written words both deepen and expedite pupils' apprehension, and it is also a good technology tool for gathering, creating, analysing, and combining visual images with the written text."

Digital storytelling also aids the teachers as an excellent instructional tool where teachers can adapt and adopt, according to the content and topic, based on the level of the students. Reference [35] strongly believes that digital storytelling is a suitable mechanism for all language production skills as it is an engaging, motivating, and creative tool for learners. It will enable the learners to make connections with past experiences combining it with their imagination and associate it with the language to put it into words. Digital storytelling is also a powerful learning tool for students as they can make their own digital stories related to their content, which enhances their comprehension of the content [25]. It concentrates on the process of producing a story where along the way the pupils strive to produce an excellent product.

Problem Statement

Rapidly declining standard in English proficiency among ESL learners, in particular, producing written work, demands the teachers to go all out to help and identify a suitable instruction method so that they will not fail in their English examination. Reference [14] highlighted that the proficiency level of students in Malaysia not even up to a satisfactory level even though English has been taught for 11 to 13 years in school. According to the Annual Report 2018 of Malaysian Education Blueprint 2013-2025, in the year 2017 , it is reported that on $73.6 \%$ passes, and in the year 2018, 74.65\% passes in UPSR (Primary School Achievement Test). In Malaysia, at the end of six years of primary schooling, the pupils required to sit for a compulsory National level examination, and English is one of the subjects which will be tested. English Paper 1 is a combination of a multiple-choice test and subjective questions where pupils will be tested on vocabulary, grammar, spelling, punctuation, and reading comprehension. Paper 2 is all about writing.

The pupils often demonstrate a lack of confidence in answering the UPSR English paper 2 as it requires language knowledge, creativity, and much thinking. Story creation is an activity where children find joy, and it turns out to be the most disliked activity when it becomes a part of an examination, and the methods of teaching such a subject vary in schools.

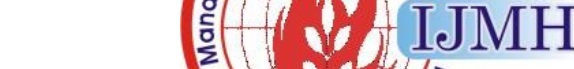
Blue Eyes Intelligence Engineering \& Sciences Publication (C) Copyright: All rights reserved. 
Narrative writing activity always perceived as a tedious, complex, and challenging task for pupils. The changes made in how we acquire and utilise the language demand a variety of new instruction methods for teachers, especially in ESL classrooms. "Lack of knowledge in creating a story hinders the writing process itself because producing a narrative requires ideas and knowledge on characters involves, the setting of the story, descriptions, and sequence of events need to be written cohesively to demonstrate the content and idea of the story" [20]. Often times, the learners associate narrative writing with challenging and impersonal examination tasks which do not allow much communication even before trying to produce a written work. As pupils always being pressured to produce narrative writing, they tend to be more reluctant and do not enjoy the process. According to [1] writing requires thought processes and cognitive processes to be produced. It allows the learner to express ideas or experience competently in other languages. Learners struggle because they are not competent to put their thoughts into words. They need assistance in organising the ideas to write a good narrative text.

\section{Purpose of Research}

The purpose of this research is to explore the use of Digital Storytelling in teaching plot in narrative writing for year-4 pupils in a primary school.

\section{Research Questions}

The research questions guiding this research are:

How does Digital Storytelling enhance year-4 pupils' understanding of plot development in narrative writing?

What are the perception and beliefs of year-4 pupils' about the use of Digital Storytelling in improving plot development in narrative writing?

\section{LITERATURE REVIEW}

\section{A. Theories related to the study}

Reference [53] Reference [53] describes, "cognitive as a term related to psychology and action or process of acquiring knowledge through reasoning, intuition or senses comprises the nature of knowledge and application focusing on an active role of the human cognitive scheme." Sociocultural processes assist form how individuals behave and construct knowledge according to [6] Social Cognitive Theory. According to that theory, three factors shape how a person thinks, feels, and behaves.

Bandura states that all three factors interact with one another in a model of triadic reciprocal determinism. Behavioural, personal, and environmental factors all interact with one another at varying degrees of magnitude to affect learning [6]. In this study, a behavioural factor is pupils' writing product, and the environmental factors were the different learning situation of the pupils. For instance, in this study, only a group of pupils will be taught using the intervention while the other will be taught using a traditional method to produce the narrative text. On the other hand, the personal factors are pupils' writing self-efficacy (which includes prior writing knowledge and achievement) and writing motivation [56].

Another theory that suits this study is Vygotsky's social learning theory (1978), which closely related to active learning. The main idea of this theory is social learning, or social constructivism, which encourages collaborative, social interactions and allows the teacher to be a facilitator. The role of pupils is to be in charge of their own learning [49]. Pupils who shown poor results will enter the Zone of Proximal Development (ZPD) if they are paired with someone who has more knowledge or skills. This will enable the pupils to maximize learning via collaboration with someone more knowledgeable, like their peers or teachers. During this zone, pupils believed in making sense of what they are learning and being introduced to. Working together on the learned concept with another person who understands it, and ultimately helps in comprehension of the topic. Digital Storytelling will be helpful in facilitating active learning enables pupils to collaborate while producing narrative writing.

\section{B. The importance of Plot development in Narrative Writing}

"Writers who are not interested in their product often have difficulty expressing their thoughts coherently because they focus too much on the vocabulary and grammar, or get trapped in the endless act of writing a line and then scratching it out again and again"[45]. Reference [36] expresses that, "a narrative must have structure, a shape or a pattern. It is being represented graphically below" [36].

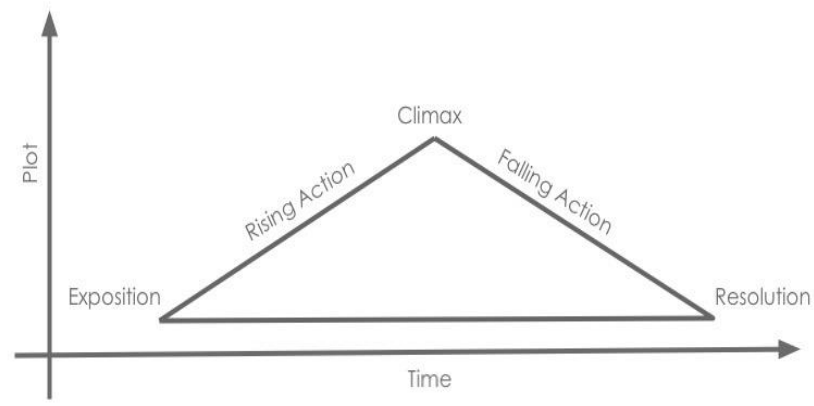

The Freitag Triangle

The Freitag triangle is made of:

1. The composition which introduces the characters and setting.

2. Rising action refers to a series of events with conflicts that lead to the climax.

3. The climax is a critical event that needs a solution.

4. The falling action is the event that drops from the highest point of excitement.

5. The resolution is about the result or conclusion.

It is essential for ESL Learners to know the structure of the narrative text to produce good narrative writing. A plot is an abstract representation through which every single event are incidental to each other and develop meaning within a communal context [46]. This will guide the pupils to put their ideas in a systematic order. A Logical progression of plot in narrative writing not only will help the writers to write incorporating the elements of suspense with guidance but also will attract the readers to follow and understand the storyline. The plot in narrative writing and digital storytelling is closely related as it adds essence to the writing. 


\section{A. Narrative Writing}

"A key of apprehending narrative is a sense of plot, theme, characters, events, and how they relate"[5]. According to [11], "narrative is structured around the chronological evolution of events and is centred on a person or hero." The narrative mostly personalised, and it tells about the circumstances related to the individual or others narrative is a story that is created in a constructive format (written, spoken, poetry, etc.) that describes a sequence of fictional of non-fictional events" [40].

"Narrative is a composition that precisely tells the activities or events in the past that show problematic experience. Resolution, on the other hand, means to amuse frequently by providing a moral lesson to the readers"[39]. The narrative plays a strong social role and acts as an agent of a social agent that changes opinions and attitudes besides acting as an entertainment for the readers. [39] believes, "narrative has been and continues to be such a favourite genre, and it is a genre that is popular among young writers." They chose it naturally to write because of its unique and fun elements.

\section{B. Social function of narrative writing}

"The social functions of narrative text are to entertain, amuse, and describes actual and vicarious experience" [22]. Reference [31] argues that narrative has a social function where it acts as a medium of entertainment and creates a platform to exchange social opinions. As for narrative writing in primary school, pupils always asked to write a story with moral value and positive concept. Reading a narrative text makes the reader resonate with the writer, as it affects their emotion and entertains them. The narrative can be used as an influencing agent of the readers. According to [27], "when stories become narratives, it gives legibility to lives; those lives become a lesson for the readers." Reference [27] also states that "narratives give clarity, and reinforces moral values, which on a practical ground has an underlying purpose of demonstrating how one should live."

Reference [27] affirms that stories will also elevate readers' moral ground, which would guide them, especially during times of trials and troubles". Narrative writing acts as a source of affirmation and helps readers to cope up with their personal struggles. It can be assumed that readers benefit socially by receiving affirmation and eased during the times of trials and struggles through narratives that are written based on real-life social environments.

\section{Digital Literacy in Malaysia}

Political, social, and economic systems in this 21st century and competitive global market resulted in producing a generation equipped with the knowledge and advanced with information communication technologies (ICTs). "This directly impacts the educational institutions, policy-makers and teachers and challenging concepts that are taken for granted, such as knowledge, information, and ability" [55]. Reference [12] explains "digital literacy as the power to discover, understand, exercise and transmit information from many sources." The ever-changing technology impacted our education system directly. Digital literacy has become the survival skill of pupils nowadays.

Digital literacy education has been integrated into the school curriculum as s step towards equipping a young generation to participate in the global market. There is who are concerned. A good story needs good content. "A

evidence showing that, "there were rapid growth and development on digital literacy and transformation in Malaysian educational programmes, plans, and policies" [13 $\&$ 21]. As a result, "the Malaysian Government never failed to initiate numerous programmes such as the Malaysian Smart School Project (MSSP), My School Net and the Electronic Book Project, to ensure ICT become a vehicle for knowledge dissemination and knowledge sharing in schools"[12].

Integration of digital literacy is an idea that promotes project-based learning, creative and critical thinking skills, problem-solving skills, and fun yet meaningful learning. Reference [9] argues that pupils need to master digital literacy like all the other skills that have been emphasised by the education ministry. There are no clear guidelines about digital literacy in Malaysian Education blueprint or any form of digital literacy policies. However, it is said to be incorporated in education from primary school to higher education [47]. Digital literacy transformation will only occur if there is a transformation in actual classroom practices besides in subject syllabuses. Proper guidelines and training for teachers are required to create a generation that is advance in digital literacy. Pupils' learning process of narrative writing will be made meaningful and effective if digital literacy has given more attention in the classroom.

\section{Studies of Digital Storytelling in Classroom}

There are many types of research have been conducted all over the world on digital storytelling in the classroom. Reference [32] examined how digital storytelling affects pupils' motivation to write as a step in preparing them to face the 21st-century world. Through the usage of qualitative research design and case study approach, the data was gathered. The researcher used purposive sampling, and the instruments used were interviews, observations, and student work and compared continuously throughout the study of four to six weeks. The results suggest that, "digital storytelling has the power to not only improve student motivation towards writing, but also improve student selfperception, creativity, and overall writing performance on a four-point grading rubric" [32]. The study suggests that as teachers, it is important to incorporate technology and digital literacy into daily instruction because students will find relevancy and highly motivated.

On the other hand, the study also highlighted some negative opinions in using digital storytelling in the classroom. The usage of digital storytelling is timeconsuming for both parties. Both teachers and students need time to use digital storytelling, where the teacher needs time for preparation. As for the students, they need time to edit and familiarise themselves with the technology.

Reference [23] researched on "Using digital stories and iPads to promote writing skills, writing self-efficacy, and motivation to write among 9th-grade students". It is similar to this study because digital storytelling used as a prewriting strategy, and it is conducted as a quasi-experimental study. Sixty-two 9th grade who aged between 15 to 16 years old students in a suburban public high school, participated in this study. It appears that technology selfefficacy predicted a student's level of writing self-efficacy at the end of the study.
Published By:

Blue Eyes Intelligence Eng \& Sciences Publication (C) Copyright: All rights reserved. 
The study also highlighted the shortcomings of digital storytelling. This study also found that using digital storytelling consumes a lot of learning time. He also adds that confidence in using technology affects the students' performance in producing digital stories.

An experimental study by [52] examined, "10th-grade students, using quasi-experimental study in two different English as a Foreign Language classes". The same content was taught for the two different classes. However, different approaches were implemented - one class was taught with digital storytelling, while the other with lecture-type, information-technology-integrated instruction" [52]. The scores of English language test, critical thinking scores, and data on motivation to learn was evaluated. The findings revealed that the group which used digital storytelling outperformed the other group. The study concluded that, "digital storytelling in English as a Foreign Language classroom able to create an efficient learning environment"[52].

\section{METHODOLOGY}

A mixed-methods design is used in this study, where it is defined as the integration of at least one qualitative and one quantitative research element. According to [29], "for broad and in-depth comprehension and corroboration purposes, a researcher combines components of qualitative and quantitative research approaches such as the data collection method, data analysis method. Then the data were triangulated for further discussions". Reference [24] suggests that "triangulation is used to seek convergence, corroboration, correspondence of resolution from different methods."

According to [41], "quasi-experimental design is used to measure the successfulness of an intervention when the intervention that has been applied by teachers before the evaluation procedure." 30 pupils were selected through the usage of purposive sampling and distributed evenly for both the control group and the experiment group. The purpose of a comparison group is so that "researchers can determine what outcome may have occurred had the treatment group not received the treatment. It is important to note that a comparison group should be as alike as possible in as many dimensions as possible" [44]. The first group is the experimental group, which was given a new treatment, or in this case, the group was taught by digital storytelling. In contrast, the second group is the control group, which is taught by the conventional method. The data was collected with a treatment using pre-test and post-test. The pre-test was used to check the quality of the subject of the study before they get the treatment. The post-test is employed to know whether there is an improvement in their writing ability after they get the treatment. The result of the test computed statistically. The design of the experiment described as the following:

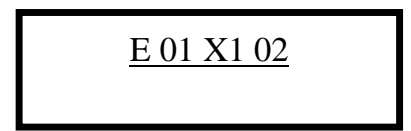

Fig 2 Design of the experiment

Source: Arikunto. 2006

The description is given below:

$\mathrm{E}$ : Experimental group

$\mathrm{C}:$ Control group
01 : Pre-test for the experimental group

02 : Post-test for the experimental group

03 : Pre-test for the control group

04 : Post-test for the control group

$\mathrm{X} 1$ : Treatment using digital storytelling

X2 : Treatment using the conventional method

\section{A. Research Participants}

\section{Population}

The population of this study is the year-4 pupils in an urban school in Kuala Lumpur, Malaysia.

\section{Sample}

Based on purposive sampling, the researcher selected 30 year-4 pupils who were of the same level from two different classes in that school. The samples are not proficient ESL learners, but they are just intermediate level learners.

\section{B. Data Collection Techniques And Instruments Used}

Two instruments were used to collect data, which is pretest and post-test. As for the pre-test, the pupils were asked to produce a narrative text without stressing on the plot of the story to know pupils' performance in writing narrative text and find out baseline data as a starting point of the study. The writing post-test was conducted, and pupils were reminded to focus on the plot of their narrative. This test was conducted to measure the overall development and skill area improvement.

\section{Pre-test}

A pre-test is a test given before the treatment. The purpose of the pre-test is to discover the prior knowledge or ability of the samples before the treatment.

\section{Treatment}

The processes carried out with the experimental group during the application process. In this case, digital storytelling was used to teach narrative text and plot development in narrative text. The treatment was presented to the samples before the post-test was administered. The experimental group was taught narrative writing using digital storytelling. They were a few steps involved in using Digital Storytelling and briefly explained below:

\section{Determining the plots of digital stories:}

Pupils were shown videos of digital stories in this phase. The plots of digital stories highlighted for each story per session. Pupils encouraged to involve in an interactive discussion about the character, setting, and mainly the plot of the story. Pupils also encouraged to identify the events in the story based on the elements of the plot. According to [30] the plot consist of, "The Orientation (established the characters and situation), Rising Action (series of complication leads to the climax), the Climax (critical moment), Falling Action (the moment away from the highest peak of excitement), and Resolution (the result or outcome)." Narratives videos of digital storytelling, which are similar to the expected narrative product of pupils was used in this phase. 


\section{Building a written scenario:}

Every pupil was aware that the plot of the digital story by analysing the video showed and by involving in the discussion. Then the pupils allowed to write their story similar to the story shown based on the plot discussed. It is merely like a parallel writing activity by using a similar plot but with different characters and settings. This phase is just to get the main idea of the narrative text, and it is a prewriting strategy. No emphasis was placed on the language, as it focused on the flow of the story.

\section{Sectioning the scenario:}

In this phase, pupils decide on suitable pictures to be used in explaining the situation of the story. The sections were based on the elements of the plot. The story was sectioned based on each element of the plot discussed in the previous phase.

\section{Making videos:}

Digital storytelling software like story jumper is used in creating the videos. Pupils write according to the plot and visuals that they have created. Background music and recordings of narrations were added later in the completion of the story. Then the final product was shared with their friends, which will help them to improve the writing selfefficacy.

\section{Post-test}

A post-test was conducted after the treatment. The posttest functions as a tool to measure pupils' abilities after they received the treatment. The post-test given was the same as the pretest.

\section{Document Analysis}

Besides, pre-test and post-test document analysis were also used as an instrument to gather data. This method helps in finding answers for research on how digital storytelling enhances year-4 pupils' understanding of plot development in narrative writing and to explore how digital storytelling improves year-4 pupils' narrative writing. Document analysis is referred to as a systematic procedure used to review or evaluate documents used in a study. "Document analysis is used to examine and interpreted the data to elicit meaning, gain understanding, and develop empirical Knowledge" [15]. By analysing the pupils' work, the researcher can thoroughly identify the improvement of the pupils before and after treatment is applied.

\section{Interview}

Another instrument used in this study is a SemiStructured interview. Semi-structured interviews perceived as, "dialogues between researcher and participant, guided by a flexible interview protocol and supplemented by follow-up questions, probes, and comments" [16]. Reference [19] states that semi-structured interviews used in small-scale research because it is a very flexible technique to be used. It begins with general questions or topics [4] as a preparation, only the topics were identified rather than the questions with an assumption that specific questions and topics would emerge during the interview session. The researcher opted for this instrument because it provides the interviewer freedom to a certain extent, to identify issues as a topic of course rather than pre-assumptions of the issues.

\section{Feedback Form}

A simple feedback form was used to gather information about pupils' opinions on the use of Digital Storytelling and how it helps them. This form is used to find out if the pupils like learning through digital storytelling and if it helps them to improve their narrative writing besides to find out if Digital Storytelling makes learning fun and engaging.

\section{Data Analysis Plan}

Two steps were used to analyse the pre-test and post-test data as below:

1. Tabulation of the data where the scores of the test arranged in rank order.

2. Applying the appropriate formula for analysing the data. The data obtained were analysed to get the eventual result. Then, the data were analysed using the t- Test formula.

$$
t=\frac{M x-M y}{\sqrt{\left(\frac{\sum x^{2}+\sum y^{2}}{N x+N y-2}\right)\left(\frac{1}{N x}+\frac{1}{N y}\right)}}
$$

Where:

Fig 3 t-test formula

$\mathrm{Mx}$ : the mean score of the experimental group

$\mathrm{My}$ : the mean score of the controlled group

$\mathrm{Nx}$ : the number of students of the experimental group

$\mathrm{Ny}$ : the number of students of the controlled group

$\mathrm{x} 2$ : the total of the square deviation of the experimental group

y2 : the total of square deviation of the controlled group

After tabulating the test scores, the computation was made. The differences between the mean scores of both the experimental group and the control group showed a significant difference among them. The formula below was used to get the mean scores:

$$
\text { mean }=\frac{\sum X}{N}
$$

Data from the semi-structured interview will be coded and analysed thematically. Data on year-4 pupils' perception about how digital storytelling improves the plot development in narrative writing will be grouped into common themes and analysed. Coding is the process of idea and concept generation from raw data [7]. In this process, ideas, concepts, and categories are identified, organized, and systematised. The data from the feedback form also analysed thematically to find out pupils' opinions and perceptions of digital Storytelling. Document analysis was used to identify strengths, weaknesses, and progress made by the pupils. The data obtained from all five instruments will be triangulated and discussed in the following chapter, focusing on the validity, reliability, dependability, and transferability aspects. 


\section{FINDINGS}

\section{A. Analysis of the Pre-Test and Findings}

The pre-test was used as a tool to detect pupils' basic narrative writing skills, and it was given before the intervention. It focussed on an organisation (plot or logical sequence), idea exposure (details), characters (major and minor), suspense, and conflict, as stated in the scoring rubric. Both the Experimental group and the Control group assigned to write their narrative in the past tense. The question required pupils to write a story between 80 - 100 words based on a picture and some helping words. Before the test, pupils brainstormed ideas for the story. Based on the picture, pupils were asked to list out related nouns, adjectives to describe the characters, settings, and verbs based on the actions depicted by the characters in the picture. The products then collected for scoring based on the suggested rubric. As shown below, both the Experimental Group and Control group showed two (2) pupils with poor performance, six (6) pupils with low performance, five (5) pupils with average performance, and two (2) pupils with good performance in each group respectively.

The formula (1) was used to calculate the Pre-Test mean. The mean score indicates that the pupils in the Experimental group scored an average score of $47.93 \%$ out of $100 \%$ possible. Whereas, the Control Group had a score of $47.86 \%$ as the average score out of $100 \%$ in the Pre-test, which produces narrative writing.

The next step was to calculate the standard deviation, where the mean score is subtracted from each score to determine the distance (D) of individual scores from the mean score $(\bar{x}-x)$. The $\mathrm{D}$ values squared individually and the sum of $\mathrm{D}$ values divided by the total number of testtakers minus one. This formula below is used to calculate the standard deviation.

$$
S=\sqrt{\frac{(X-\bar{X})}{n-1}}
$$

The standard deviation for the experimental group is 17.59, whereas the standard deviation for the controlled group is 18.48. The dispersion of test scores around the means for both groups is similar, as there were no significant differences between both groups, which indicates that pupils in both groups are heterogeneous and are of almost the same level. Both groups have pupils who are poor, low, average, and excellent proficiency in writing narratives equally.

\section{B. Analysis of the Post-Test and Findings}

The Post-test was given to both controlled and experimental groups after the intervention stage. The PostTest also focussed on the organisation (plot or logical sequence), idea exposure (details), characters (major and minor), suspense, and conflict, as stated in the scoring rubric. Both the Experimental group and the Control group assigned to write their narrative in the past tense. The question required pupils to write a story between 80 - 100 words based on a picture and some helping words. Before the test, pupils brainstormed ideas for the story. Based on the picture, pupils were asked to list out related nouns, adjectives to describe the characters and settings, and verbs based on the actions depicted by the characters in the picture. The products then collected for scoring based on the suggested rubric. The Post-Test scores showed that ten (10) pupils from the experimental group performed well. Whereas, in the Controlled Group, only six (6) pupils performed well. The analysis of Post-Test scores illustrated below for both groups.

The mean score indicates that the pupils in the Experimental group scored an average score of $65.6 \%$ out of $100 \%$ possible. The Control Group, on the other hand, scored $56.8 \%$ as the average score out of $100 \%$ in the Posttest, which is to produce narrative writing. The next step was to calculate the standard deviation, where the mean score is subtracted from each score to determine the distance (D) of individual scores from the mean score $(\bar{x}-x)$. The $D$ values squared individually and the sum of $D$ values divided by the total number of test-takers minus one. Formula (2) is used to calculate the standard deviation. The standard deviation for the experimental group is 11.95 , whereas the standard deviation for the controlled group is 16.25. Both groups show an improvement of mean scores in the Post-test compared to Pre-test. The experimental group shows a higher growth, which is from an average score of 47.93 to 65.6 . On the other hand, the controlled group shows signs of growth from 47.86 to 56.8 .

TABLE 1 PRE-TEST AND POST-TEST MEAN PERCENTAGE OF GROWTH

\begin{tabular}{cccc}
\hline GROUP OF PUPILS & PRE-TEST & POST- TEST & GROWTH(\%) \\
EXPERIMENTAL GROUP & 47.93 & 65.6 & 36.86 \\
CONTROLLED GROUP & 47.86 & 56.8 & 18.68 \\
\hline
\end{tabular}

Based on the results of the Post-Test, it can be concluded that there is an improvement in pupils' narrative writing skills for both groups.

\section{Test of Significance}

Besides the comparison of means, a t-test also used to determine the significant difference between the two groups statistically. The t-test formula discussed previously used to strengthen the analysis results.

The value of the t-test then compared with the critical value of $\mathrm{t}$-table to check if the differences in the mean are significant. $\sigma=5 \%$, and the t-value found from the table is 1.701. The calculations revealed that the $t$ value (1.711) is higher than the critical value found in the t-table (1.701). As previously mentioned, there is a significant difference between in improvement of the experimental and controlled group after the treatment.

\section{Thematic Analysis}

Themes were identified in order to analyse the qualitative data, which is the document analysis, feedback form, and semi-structured interview. Several pupils' works were picked to analyse the difference between before and after treatment. The feedback form also was analysed based on the three themes below. Transcribed interviews analysed based on themes to answer the research questions.

1. Pupils' improvement in terms of plot development and organisation. 
In this aspect, pupils' improvement can mostly be seen in how they organise the story based on the documents analysed. The development of the plot can be seen clearly. They improved on how to keep up the flow of the story instead of just writing sentences without any storyline. The coherence between sentences improved in pupils' writing skills. Pupils learned to start with topic sentences and followed by supporting details, which helped them to maintain a decent plot development and helped them to score better marks in the post-test.

Besides that, in the interview session, pupils were asked if Digital Storytelling helped them to focus on the plot of the story while writing the story and does it made them better writers. All four of them agreed, and they also showed their understanding of plot development.

"Now, I always plan my story first."

"watch the video then find the beginning, conflict ending.. so I also use that la teacher when I write".

"Hmm.... I must draft my plan the ... what ah... ahh the setting... the conflict and how to solve the problem like Ejen Ali" (Agent Ali).

Their response shows they truly understood the importance of plot in and organisation in writing a story. As all 15 of them draw a happy face in the feedback form for the statement, "When I write a story, I make sure that I will be focusing on the beginning, rising action, conflict, climax, falling action, and resolution." Pupils in the experimental group benefited from Digital Storytelling.

2. Pupils' improvement in terms of content and word counts.

Pupils also mentioned that using pictures makes them think of good characters and setting, which helps them to write more words and describe everything a little more in detail. Pupils took initiatives to write the number of words in the post-test, as shown in the picture below. The relation between the characters and paragraphs shows pupils' understanding of the content. Based on document analysis, even though the content in the Pre-test good but there was a lack of details. By the end of the pre-test, they were able to develop the problems with good flow and able to get hold of the sequencing of events.

As for the interview, pupils mentioned they want to write more because they get to insert pictures and sounds. They learned to give importance to the content, which is the setting, storyline, and utilise more verbs to demonstrate actions.

"I want to write more."

"Now I write a very long story because baru boleh

letak gambar and insert music semua with

Aliya"(then only I can insert $t$ music and pictures)

"We can see who is a story better.. who can write more and get more marks".

Interestingly, 10 out of 15 pupils draw a happy face in the feedback form for the statement, "Now I learned to describe the setting and character while writing a story." which indicated that pupils learned to focus on content and word counts of the stories.

Digital storytelling motivates pupils to be a better writer.

It is also found that some pupils motivated to write more stories because of Digital Storytelling from the interview session. They said that it is a very interesting activity and they do not feel bored or sleepy, especially when they can compare with their friends. They feel excited to produce a narrative.

"now I write a very long story because of baru boleh letak gambar and insert music semua with Aliya (friend). (then only I can insert t music and pictures)

"We want to write more stories about us."

"happy... I can create like my own book.. uhhh... nice la teacher".

"I feel great and happy la teacher. I don't feel sleepy or boring to write stories ready."

"I love using it.. I got many stories ready to create."

"we can see who's story better."

"I fell excited la... hmmm to create problems and characters to solve the problem, teacher..."

Based on the feedback from 11 out of 15 pupils who drew a happy face for the statement, "Using Digital storytelling makes me a happy writer." 12 out of 15 pupils draw a happy face for the statement "Digital Storytelling makes me write multiple stories," and 11 out of 15 pupils draw a happy face for the statement "Digital Storytelling helps me to be a confident writer." Digital Storytelling helped pupils to be happy writers, better writers, and confident writers.

\section{DISCUSSION AND CONCLUSION}

\section{A. Discussion Of The Findings}

The research covers two research questions which will be discussed in reference to the literature reviewed earlier.

Research Question 1: How does Digital Storytelling enhance year-4 pupils' understanding of plot development in narrative writing?

The results of this study revealed that Digital Storytelling enhances year-4 pupils' understanding of plot development in narrative writing. The mean analyses of data showed that pupils from an experimental group who practised narrative writing using Digital Storytelling in the classroom had higher growth in their post-test scores compared to the pupils in controlled groups who practised narrative writing using the convention method. These results are similar to the experimental study of [52], whereby it was also found that the group which used digital storytelling outperformed the other group.

As discussed earlier, [10] says that, "integration of visual images with written text not only deepens and improves pupils' comprehension but also acts as a good technology tool for collecting, creating, analysing, and combining visual images with the written text." The interview sessions with pupils indicated that pupils enjoy the writing process and they learned to pay more attention to the plot development of a narrative that they are writing because of the use of pictures. They want to write about setting and characters as well because they can insert suitable pictures. Thus, this became a practice of whenever they write a story, in which the plot would be used as a guide to ensure that it does not alter the contexts of the story. This habit also helped them to increase their word count in producing narrative writing. It matches the findings of [43], "the students transform to be better attuned to the language learning process if teachers put the process of writing as the focus of their teaching instead of stressing on the products of the writing." Digital Storytelling focussed on the process, and it eventually helped pupils to improve the product. 
The document analysis and feedback form also proved that pupils positively impacted on keeping track of the flow of the story where they think every story must have beginning, rising action, conflict, climax, falling action and resolution had experienced a meaningful learning. They have improved in organizing their idea after using Digital Storytelling. Similarly, [53] found some advantages of integrating ICT in writing instruction were that it could draw pupils' attention, facilitate pupils' learning process, it helps to enhance pupils' vocabulary and promote meaningful learning.

2.Research Question 2: What are the perception and beliefs of year-4 pupils' about the use of Digital Storytelling in improving plot development in narrative writing ?

The interview and feedback form helped the researcher to explore on the beliefs and perspectives of pupils about the use of Digital Storytelling in improving plot development in narrative writing. Below listed are the three major discoveries of beliefs and perspectives of pupils.

a) Pupils are motivated to write a narrative using Digital Storytelling.

From the analysis of the interview and feedback obtained, it can be concluded that pupils feel encouraged to produce narrative writing because it is an interesting activity and engaging. They want to create their own product. As found by [32] that as teachers, it is important to incorporate technology and digital literacy into daily instruction because students will find relevancy and highly motivated. In this case, Digital Storytelling is relevant for pupils, and it helps them to create better stories.

b) Pupils enjoy the writing process using Digital

Storytelling.

In the interview sessions, pupils also stated that they feel happy and excited to write using Digital Storytelling. Most pupils from an experimental group also indicated a happy face in a feedback form as a sign of agreement that they feel happy, they want to write more stories, and they feel confident to write more narratives using Digital Storytelling. Features such as inserting their own pictures, designing the book, and inserting suitable sounds and music - all of which amuse them and help them to give life to their imagination. The pupils get excited when they found a way to share their idea. As for the subject in matter in [38] states, that pupils who go through authentic mastery experiences gain success. Specific goals and frequent feedback will ensure pupils develop necessary mastery experiences to become better writers. When pupils' self-efficacy increases, especially in this case, the mastery of Digital Storytelling, they become good at narrative writing.

c) Digital Storytelling encourages collaborative learning.

The last belief and perspective of pupils, which the researcher identified through an interview, is that the pupils' belief on Digital Storytelling which creates opportunities for them to write stories and create their digital videos or books together with their friends. The spirit of positive competition also instilled among pupils as they want to see who score better marks. They are also eager to see their friends work on how it differs from theirs. Vygotsky's Social Learning theory pointed out that when a weak individual is paired with a competent individual, they will enter the zone of proximal development(ZPD) where they will be able to maximize their learning. This theory encourages collaborative learning, just like Digital Storytelling.

\section{B. Summary Of Findings}

The findings indicated that pupils positively improved the understanding of plot development in narratives. Using Digital Storytelling improved pupils' narrative writing in terms of word count, awareness of major and minor characters, setting, the content, the storyline, and the flow of the story. It is also found that Digital Storytelling motivates pupils to write confidently, enjoy the writing process, and love the task that they are doing. The sense of excitement and competitiveness boost their narrative writing skill and encourages collaborative learning. Pupils have a positive perspective and beliefs in using Digital Storytelling as it helps them to improve their understanding of plot development in producing narrative writing. The findings of this study also corroborated with the literature reviewed earlier.

\section{Implications Of Research}

The findings in this research revealed that Digital Storytelling is a potential strategy that can be adapted by educators to improve narrative writing skills in schools. In the hopes of creating awareness among the teachers to utilise technology and integrate it according to the needs and levels of the pupils so that it will result in positive impacts on teaching and learning. Even though teaching writing skill is not an easy task through this study, it is proven that it is possible to make learning meaningful and interactive, which eventually help pupils to show improvement in their writing skill. This study also will add to the literature pool related to Digital Storytelling, especially in terms of improving understanding of plot development in narrative writing.

\section{Limitations Of Research}

Since this is a quasi-experimental study, and only a small group of pupils were selected to study the impact of Digital Storytelling, the findings cannot be generalised for all year-4 pupils. Using technology in the classroom also is timeconsuming, as highlighted by [32]. Similarly, both teachers and pupils need to spend much time exploring the application and in producing the Digital Story. Handling pupils who are technology savvy also another challenge as they tend to do other things while they are not monitored. The teacher needs to have careful planning and experience before using it in the classroom.

\section{E. Recommendations For Further Study}

Some recommendations for further studies include enlarging the scope of study in terms of the number of participants and also conduct the research in rural areas. The research also can focus on pupils' language and plot development in producing narrative writing as it is the basic foundation for producing narratives. It is also suggested that more types of instruments to be used to gather and analyse data in detail for the triangulation of data.

\section{CONCLUSION}

In conclusion, the use of Digital Storytelling in teaching plot in relation to narrative writing for year-4 pupils in a primary school is an effective strategy. It helps both the teachers and pupils to make writing an interesting narrative task. 
It acts as a tool that facilitates learning and as a motivating medium in writing classrooms. Teachers can utilise this tool and adapt according to the needs of their pupils to make learning engaging and project-based. It is also aligned with $21^{\text {st }}$-century teaching and learning requirements. Teachers need to be more creative in helping pupils to master writing skills and help them to love their learning. It is a flexible, easily accessible, and effective tool in teaching wring skills. Teachers just have to make sure pupils are not just passive recipients of knowledge, but active learners who involve themselves in the classroom to make sure they maximise their learning ability.

\section{REFERENCES}

1. Abdel-Hack, E. M., \& Helwa, H. S. A. A. (2014). Using Digital Storytelling And Weblogs Instruction To Enhance Efl Narrative Writing And Critical Thinking Skills Among Efl Majors At Faculty Of Education. Educational Research, 5(1), 8-41.

2. Akkoyunlu, B. (2002). Educational Technology In Turkey: Past, Present And Future. Educational Media International, 39(2), 165-174.

3. Andrew, J. S. (2006). The Implementation of the 2002 Malaysia Preschool English Language Curriculum in National Annex Preschools. (Unpublished master's thesis). Penang: Universiti Sains Malaysia.

4. Arksey, H., \& Knight, P. 1999. Interviewing For Social Scientists: An Introductory Resource With Examples. Thousand Oaks: Sage Publications.

5. Anderson, M. \& Anderson, K. (2003). Text Types In English 2. Macmillan Education Australia Pty Ltd.

6. Bandura, A. (1986). Social Foundations Of Thought And Action: A Social CognitiveTheory. Englewood Cliffs, Nj: Prentice Hall.

7. Benaquisto, L. (2008). Codes And Coding. In Given, L.M. 2008. The Sage Encyclopaedia Of Qualitative Research Methods. p. 85-88. California: Sage.

8. Boardman \& Cynthia. A. (2002). Writing To Communicate (Paragraph And Essay). New York: Longman.

9. Breivik, P.S. (2005). Student Learning In The Information Age. Phoenix, Arizona: Oryx

10. Burmark, L. (2004). Visual Presentations That Prompt, Flash \& Transform. Media And Methods, 40(6), 4-5.

11. Celce, M. \& Olshtain, M. E. (2000). Discourse And Context In Language Teaching,Usa: Cambridge University Press.

12. Chan, F. M. (2002). Developing Information Literacy In Malaysian Smart Schools: Resource-Based Learning As a Tool To Prepare Today's Students For Tomorrow's Society In: Singh, D Et Al. (Ed.) School Libraries For a Knowledge Society. Proceedings Of The 31st Annual Conference Of The International Association Of School Librarianship, Petaling Jaya, Kuala Lumpur, Malaysia (4-9 August, 2002). Seattle, Wa, Iasl: 203-215.

13. Chan, S-N. (2003). Making Information Literacy a Compulsory Subject For Undergraduates: The Experience Of The University Of Malaya. Ifla Journal, 29(4), 328-335.

14. Chung, J. \& Melor, M. Y. (2016). Digital Storytelling Production As a Learning Tool In Improving Esl Learners' Verbal. Asian Efl Journal Professional Teaching Articles, 3(90): 1-106.

15. Corbin, J. \& Strauss, A. (2008). Basics Of Qualitative Research: Techniques And Procedures For Developing Grounded Theory (3rd Ed.). Thousand Oaks, Ca: Sage.

16. Dejonckheere,M \& Vaughn, L. M. (2019). Semi-Structured Interviewing In Primary Care Research: a Balance Of Relationship And Rigour Family Medicine And Community Health 2019;7:e000057. Doi: 10.1136/Fmch-2018-000057.

17. Deore, K. V. (2012). The Educational Advantages Of Using Internet. International Educational E-Journal, 1(2), 111-112.

18. Derewianka, B. (1990). Exploring How Text Works. Nsw: Primary English Teaching Association

19. Drever, E. (1995). Using Semi-Structured Interviews In Small-Scale Research. A Teacher's Guide. Edinburgh: Scottish Council For Research In Education.

20. Dunn, M. W. \& Finley, S. (2010). Children's Struggles With The Writing Process: Exploring Storytelling, Visual Arts, And Keyboarding To Promote Narrative Story Writing. Multicultural Education, 18(1), 33-42.

21. Edzan, N.N. (2008). Information Literacy Via Blended Learning. Paper Presented At Konvensyen Teknologi Pendidikan Ke-19, September 911, Langkawi, Malaysia. (Unpublished).
22. Gerot, L \& Wignell, P. (1994). Making Sense Of Functional Grammar. Sydney: Antepodean Educational Enterprise.

23. Girasoli,A.J. (2016). Using Digital Stories And Ipads To Promote Writing Skills, WritingSelf-Efficacy, And Motivation To Write Among 9th Grade Students. Doctoral Dissertations. University Of Connecticut Graduate School.

24. Greene, J.C, Valerie, J, Caracelli \& Graham, W.F. (1989. )Toward a Conceptual Framework For Mixed-Method Evaluation Designs. Educational Evaluation And Policy Analysis. . 11:255-274. Doi: 10.3102/01623737011003255.

25. Hur, J. W., \& Suh, S. (2012). Making Learning Active With Interactive Whiteboards, Podcasts, And Digital Storytelling In Ell Classrooms. Computers In The Schools, 29(4), 320-338.

26. Indriyani, E. (2015). Improving Students' Writing Narrative Text By Using The Combination Of Story Sequencing Cards And Round Table Technique: The Case Of Eight Grade Of Junior High School 19 Semarang In The Academic Year Of 2014/2015 (Sarjana Pendidikan Paper, State University Of Semarang). Retrieve From: Http://Lib.Unnes.Ac.Id/20473/1/2201411 017-S.Pdf

27. Isik, N. E. (2015). The Role Of Narrative Methods In Sociology: Stories As a Powerful Tool To Understand Individual And Society. Journal Of Sociological Research. Vol 18(1): 103-125.

28. Jakes, .D. (2006). Standards-Proof Your Digital Storytelling Efforts. Tech Learning, March 2006. From [Retrieved On 25 April 2019]

29. Johnson, B.R, Onwuegbuzie, A.J \& Turner, L.A. (2007). Toward a Definition Of Mixed Methods Research. Journal Of Mixed Methods Research.(1)112-133.Doi: 10.1177/1558689806298224.

30. Karolina, I. (2006). Teaching Narrative Text In Improving Writing To Tenth Grade Students Of Sma Negeri 1 Petarukan Pemalang, 2201402513, Unnes: Semarang, p.27.

31. Knapp, P And Watkins,M.( 2005). Genre, Text, Grammar:Technologies For Teaching And Assessing Writing, University Of New South Wales Press Ltd. p. 220-22.

32. Lobello.C.( 2015). The Impact Of Digital Storytelling On Fourth Grade Students' Motivation To Write. Education And Human Development Master's Thesis. The College At Brockport: State University Of New York.

33. Manik.S \& Sinurat. J.D. (2015). Improve Students' Narrative Writing Achievement Through Film At Sma Negeri I Palipi. International Journal Of English Linguistics 5(2): 172-188.

34. Mccoog, I.J. (2008). 21st Century Teaching And Learning. Education Resource Center. $\backslash$ Retrieved From Eric.Ed.Gov/Pdfs/Ed502607.Pdf

35. Moore, S. C. K. (2009.) Caela Network Briefs Uses Of Technology In The Instruction Of Adult English Language Learners. Center For Applied Linguistics, (February), 2004-2007.Retrieved From Http://Www.Cal.Org/Caelanetwork/Pdfs/Usesoftechnologyfinalweb.Pd $\mathrm{f}$

36. Neo, Ernest. (2005). Narrative For 'O' Level. Malaysia: Longman.

37. Olstain, M.C. (2000). Discourse And Context In Language Teaching. New York: Cambridge University Press

38. Pajares, F., Johnson, M. J., \& Usher, E. L. (2007). Sources Of Writing Self-Efficacy Beliefs Of Elementary, Middle, And High School Students. Research In The Teaching Of English, 42(1), 104-120.

39. Pardyono. (2007). Pasti Bisa Teaching Genre Based Writing. Yogyakarta: Andi.

40. Purba, R.(2018). Improving The Achievement On Writing Narrative Text Through Discussion Starter Story Technique. Advances In Language And Literary Studies: (9): 27-30.

41. Shadish, W., Cook, T., \& Campbell, D.(2002). Experimental And Quasi-Experimental Designs For Generalized Causal Inference. Boston: Houghton Mifflin Company.

42. Shelby-Caffey, C., Úbéda, E., \& Jenkins, B. (2014). Digital Storytelling Revisited: An Educator's Use Of An Innovative Literacy Practice. Reading Teacher, 68(3), 191-199. Https://Doi.Org/10.1002/Trtr.1273

43. Shih, M. (1986). Content-Based Apporaches To Teaching Academic Writing. Tesol Quarterly, Volume 20, Pp. 617- 648.

44. Slavin, R. (2007). Educational Research In An Age Of Accountability. Boston: Pearson Education.

45. Sledd, R. (1993). The Dark And Bloody Mystery: Building Basic Writer's Confidence. (Eric Document Reproduction Service No. Ed 361 694).

46. Szurmak. J \& Thuna.M. (2013). Tell Me a Story: The Use Of Narrative As a Tool For Instruction. Indianapolis, In, 2013, 546-552.

Published By:
Blue Eyes Intelligence Engineering \& Sciences Publication

(C) Copyriaht: All riahts reserved. 
47. Tan, S.M., \& Singh, D. (2010). An Assessment Of The Il Levels Of Library And Media Teachers In The Hulu Langat District, Malaysia. Paper Presented At Icolis 2008, Kuala Lumpur, Organized By Lisu, Fcsit, University Of Malaya.

48. Teo, A.K. (2006). Using a Peer Assisted Writing Activity To Promote Esl/Efl Students' Narrative Writing Skills. The Internet Tesl Journal, Xii (8). Available Online At Http://Iteslj.Org/.Retreived On (19- 122013).

49. Vygotsky, L. (1978). Mind In Society: The Development Of Higher Psychological Processes. Cambridge: Harvard University Press.

50. Yamac, A. \& Ulusoy, M. (2016). The Effect Of Digital Storytelling In Improving The Third Graders' Writing Skills. International Electronic Journal Of Elementary Education, 9(1).

51. Yancey, K. (2004). Teaching Literature As Reflective Practice. Urbana, Il: National Council Of Teachers Of English.

52. Yang, Y.C. \& Wu, W. C.I. (2012). Digital Storytelling For Enhancing Student Academic Achievement, Critical Thinking,And Learning Motivation: A Year-Long Experimental Study. Computers \& Education 59, 339-352

53. Yi, X. (2004). Applied Linguistics: Language Learning And Teaching. Changchun: Jilin University Press.

54. Yunus, M. M., Nordin, N., Salehi, H., Embi, M. A., \& Salehi, Z. (2013). The Use Of Information And Communication Technology (Ict) In Teaching Esl Writing Skills. English Language Teaching, 6(7), 1.

55. Zajda. (2010). Global Pedagogies. Schooling For The Future, Dodrecht: Springer

56. Zimmerman, B., \& Bandura, A., \& Martinez-Pons, M. (1992). SelfMotivation For Academic Attainment: The Role Of Self-Efficacy Beliefs And Personal Goal-Setting. American Educational Research Journal, 29, 663-67

\section{AUTHORS PROFILE}

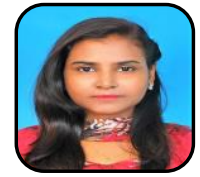

Patrisha David, is an English teacher in Primary School in Malaysia. She is also a postgraduate TESL student in Universiti Kebangsaan Malaysia. She has B.Ed in TESL. Her research interests are in integrating teaching and learning with technology.

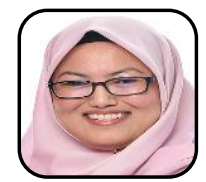

Azlina Abdul Aziz, is a TESL lecturer at Faculty of Education, UKM. She has an Ed.D in Teaching of English from teachers Collage, Columbia University, U.S.A. Her research interests are in the Teaching and Learning of Literature and Teacher Education in TESL. She is interested in how literary texts and personal narrative may be utilised to help students to examine the social, cultural and political issues in a particular context. 